\title{
CDISC SDTM Skin Response Test Code Terminology
}

National Cancer Institute

\section{Source}

National Cancer Institute. CDISC SDTM Skin Response Test Code Terminology. NCI

Thesaurus. Code C112024.

Terminology associated with the skin response test code codelist of the Clinical Data

Interchange Standards Consortium (CDISC) Study Data Tabulation Model (SDT M). 